\title{
Quartzite Karst in Southeastern Venezuela
}

\author{
By William B. White ${ }^{1}$ ), Gene L. Jefferson ${ }^{2}$ ), and Jon F. Haman ${ }^{3}$ )
}

With one figure in the text

\section{Introduction}

About $300 \mathrm{~km}$. south of Cuidad Bolivar and the Orinoco River lies Venezuela's Gran Sabana. It is a vast upland surrounded by the Precambrian rocks of the Guiana Shield. The bedrock is the Roraima Quartzite recently shown to be of lower Proterozoic Age (1.7 m.y.) by Snelling (1963). At the center of the upland is Mount Auyan-Tepui, a table mountain of quartzite rising to an elevation of 1,000 meters above the surrounding Sabana. The entire area has a mesa and butte topography with mesas ranging in size from a fraction of a square kilometer to perhaps $15 \mathrm{~km} .^{2}$. The annual rainfall on the Sabana is reported to be $1,000 \mathrm{~mm}$. but the tops of the high mesas may receive as much as $7,500 \mathrm{~mm}$. The climate is humid and hot with alternating wet and dry periods. The geology of the area has been described by Lopez et al. (1942).

In outcrop the Roraima Quartzito appears as a red, mediumgrained sandstone, often deeply weathered on the surface. Beneath the weathered zone, it is often nearly white and very well cemented. The petrographic microscope shows the rock to be an orthoquartzite becoming locally arkosic with about $5 \%$ feldspar. The grains are wellrounded, cemented with quartz, and often have quartz overgrowths. The rock breaks with a conchoidal fracture, apparently across the grain.

\footnotetext{
1) Department of Geochemistry and Mineralogy, Pennsylvania State University, University Park, Pennsylvania, U.S.A.

$\left.{ }^{2}\right)$ Stauffer Chemical Company, Green River, Wyoming, U.S.A.

3) Department of Geology, University of Utah, Salt Lake City, Utah, U.S.A.
} 
Field work for this paper was done in connection with general geological studies in the area in the summer of 1958. Observations reported here were made in that part of the Sabana immediately surrounding the village of Canaima on the Carrao River.

\section{Karst Features}

Weathering of the Roraima Quartzite has produced a number of small-scale surface features which superficially resemble karst features developed on a limestone topography. Recent discussions of karst development on granite (Klaer, 1957; Rasmusson, 1959; Wojcik, 1961) have focused attention on solutional weathering in less-soluble rocks. It is thus of interest to investigate a possible karst on quartzite. The nomenclature follows more or less the suggestions of Bögli (1960).

Karren: Tops of mesas and buttes are frequently surfaced with small pits (Trittkarren) and grooves and intermediate ridges (Rinnenkarren). The relief of groove to ridge is about 25 to $50 \mathrm{~cm}$. The pits are gently concave; the ridges are smoothly rounded, not jagged like tropical karren in limestone.

Kluftkarren: The top of a small butte near Canaima has a flattish top which slopes about $10^{\circ}$ following the dip of the east flank of the Carrao syncline. Cutting across this surface from one rim to the other are a number of crevices. They are skewed to both dip and strike and appear to be strongly joint controlled. An average crevice is 3 to 5 meters wide and perhaps 3 meters deep. The walls are very steep and in places are completely vertical. The bottom is usually swampy and may contain small puddles of water. The bottom has a divide in the middle from which water drains in both directions to the rim of the butte. After heavy rains the buttes of the Canaima region spurt numerous 500-meter high waterfalls which issue from the ends of these crevices. Tate (1938) presents a number of photographs of features on the summit of Auyan-Tepui showing deep canyons and crevices that appear to be of similar origin. Again joints seem to be the controlling factor.

Shafts and similar features: Walls of cliffs with active waterfalls sometimes show a vertical concave cylindrical depression with an outline remarkably similar to a vertical shaft in limestone. The most spectacular of these is that of Angel Falls. Behind the waterfall is a half-shaft nearly 1,000 meters high. It was seen from an airplane only and could not be examined in detail.

Possibility of caves: If the surface features are a genuine karst then the possibility should exist for solution caves in quartzite. None were 
observed in the lower buttes and valleys where weathering is not so intense, but the rim of Auyan-Tepui where weathering is at a maximum bears definate possibilities. Many of the waterfalls pour from crevices up to 30 meters below the rim but these are probably just deep narrow canyons. One small fall, however, was observed spurting from the quartzite cliff at the contact between the "A" and "B" members of the Roraima some 250 meters below the rim and 750 meters above the valley floor. No crevice was visible and it appears to be the terminus of a true subterranean drainage tube in the quartzite.

\section{Evidence for Solutional Origin}

The best evidence for a solutional origin for the land forms is derived from the petrography of the Roraima Quartzite. Thin sections of the weathered zone show that there has been a considerable amount of conversion of quartz to opal. In addition the wall of a small fissure cave discovered in the ridge above Canaima had a thin coating of opal flowstone providing further evidence for the solution and later redeposition of silica. Detailed descriptions of two representative specimens are given below:

\section{Specimen No. 1}

Location: Outcrop at lower end of Mayupa Rapids on the Carrao River. "D" member of the Roraima series.

Hand Specimen Description: Grey fine-grained very dense quartzite. Concoidal fracture. Prominent weathered border with thin hematite stained zone next to the fresh rock.

Microscopic Description: Texture: Particle size range 0.2 to $0.5 \mathrm{~mm}$. No visible bedding. Grain sphericity - fair. Grain roundness - excellent. Alteration: Intense weathering. Mineral composition: Primary-quartz; alteration products - chalcedony and opal; introduced minerals - hematite. Cementation: Authigenic overgrowths on quartz grains. Alteration processes: Alteration of both authigenic overgrowths and quartz grains to opal with some crystallization of the opal as chalcedony. Hematite occurs mostly as a coating around grain margins in areas already well altered. The inner zone (seemingly unaltered in hand specimen) shows some alteration to opal and chalcedony while in the weathered zone the individual grains are almost completely detached and altered to opal with very little chalcedony. 
Specimen No. 2

Location: Outcrop in a small fissure cave along a joint on the ridge just east of Canaima. "D" member of the Roraima series.

Hand Specimen Description: Brown, fine-grained, dense quartzite with a coating of white-grey flowstone which forms some rudimentary stalactites.

Microscopic Description: Texture: Particle size range 0.2 to $0.5 \mathrm{~mm}$. Some alignment of prismatic grains. Sphericity - fair. Grain roundness - fair. Flowstone very delicately banded. Alteration: Intense weathering. Mineral composition: Primary - quartz, 95\%; feldspar (microcline and andesine), 5\%. Secondary - opal and chalcedony. Flowstone is of opal. Introduced - hematite.

The basic mechanism of silica solution seems to be hydration of quartz to opal and leaching of the resulting gel. Several cases of boulders with indurated exteriors underlain by a mush of grains of quartz and chalcedony were noted. The hardened exterior is formed of grains of the same composition well-cemented by opal.

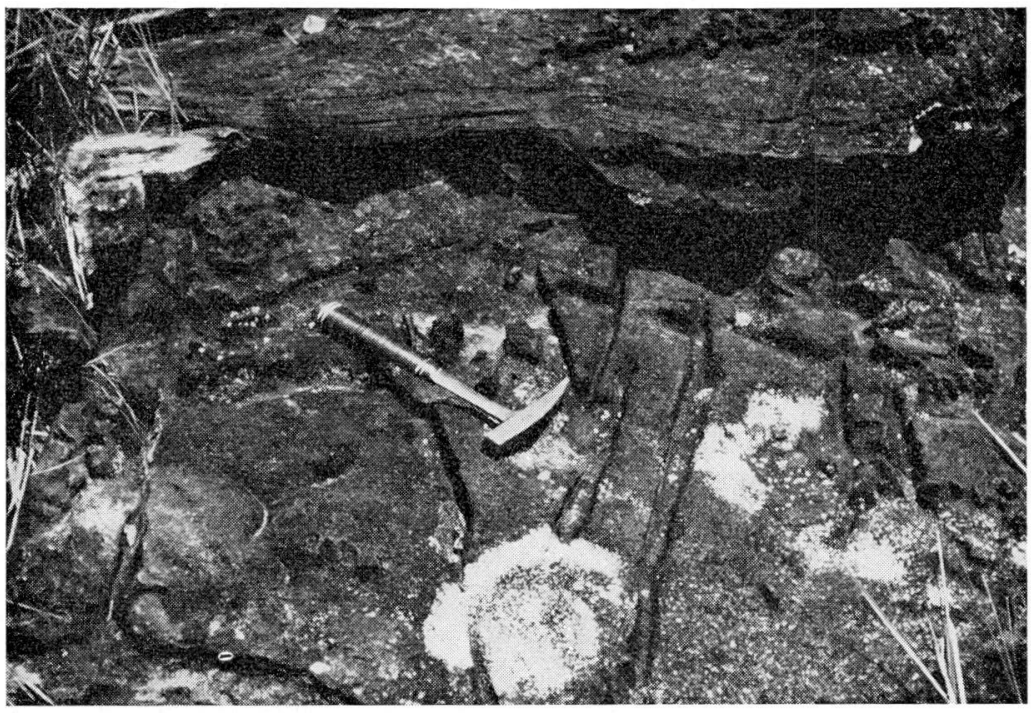

Fig. 1. Rinnenkarren in quartzite in the Carrao River Valley at about 1,000 meters elevation.

Evidence for the solutional origin of the karren is also provided by their distribution in elevation. In the valley floors karren are limited to small pits and grooves with a relief of only a few centimeters (fig. 1). 
On the tops of intermediate buttes 300 to 500 meters above the valley, the relief of the karren is of the order of a few meters. The uppermost "A" member of the Roraima Quartzite outcropping along the rim of Auyan-Tepui was observed from an airplane to be cut into jagged pinacles with a relief of tens of meters. The rainfall increases with elevation from about $1,000 \mathrm{~mm}$. at the 1,000-meter elevation of the valley floor to $7,500 \mathrm{~mm}$. at the 2,000 -meter elevation of the mountain summit. Thus solutional action apparently increases with increasing precipitation.

\section{Mechanism of Solution}

Perhaps the most important question concerns the solubility of silica under tropical weathering conditions. Krauskopf (1956) has studied the solubility of $\mathrm{SiO}_{2}$ under various conditions. The primary factor controlling $\mathrm{SiO}_{2}$ solubility is temperature, with $\mathrm{pH}$ playing a minor role up to $\mathrm{pH}$ 9. The solubility of amorphous silica is $100 \mathrm{ppm}$. at $25^{\circ} \mathrm{C}$. and reaches $400 \mathrm{ppm}$. at the boiling point of water - a value exceeding the solubility of calcite. However, these data are for amorphous silica; the solubility of crystalline quartz is about $14 \mathrm{ppm}$. Other authors such as Morey et al. (1962) place the equilibrium solubility of quartz at the much lower value of $6 \mathrm{ppm}$. However, Morey et al. note that it is possible to form supersaturated solutions of quartz with concentrations as high as $395 \mathrm{ppm}$. at $25^{\circ} \mathrm{C}$. by agitating quartz-water mixtures for 370 days.

It can be seen that the solution of quartz would be a slow process, but if the tropical climate can weather quartz to opal then solution of opal would take place nearly as quickly as limestone dissolves in temperate climates. The critical factor may be the nature of the weather in the Gran Sabana. The rock has a dark surface and early forenoon sunshine from a clear sky will raise the surface temperature of the rocks to perhaps $40^{\circ}$ to $50^{\circ} \mathrm{C}$. Around 2: 00 P.M. the sky clouds over very quickly and rain pours torrentially onto the hot surface. The amount of surface layer dissolved under these conditions may be quite high. Water soaking into the porous outer crust could activate the weathering process but subsequent evaporation of the water would leave the silica behind. Only the outer layers of the crust would be carried off in solution in each subsequent rainfall.

The necessity for extreme surface weathering offers an explanation for the lack of subsurface karst development. Only on exposure to tropical weathering conditions would rapid conversion of quartz to 
opal take place. Inside the quartzite mass the solubility remains low and cavern development would not usually take place.

However, the petrographic and chemical evidence is such that a solutional origin of the observed landforms seems feasible. Thus the term "quartzite karst" is correctly applied.

\section{ACKNOWLEDGEMENT}

We are grateful to Dr. Eugenio DeBellard Pietri for his many assistances during our stay in Venezuela and to Rudy J. F. Truffino for his services as a guide.

\section{ABSTRACT}

Minor weathering forms on the Roraima Quartzite in the Carrao River Basin of Southeastern Venezuela have the appearance of the karren that form on limestone surfaces in karst terrains. Climatological and chemical evidence indicates that these forms were generated by a solutional mechanism and that this area thus exhibits a minor karst topography on quartzite.

\section{RÉSUMÉ}

De petites formes d'érosion sur les Quartzites de Roraima dans le Bassin du Carrao, au Sud-Ouest du Vénézuela, ont l'apparence des lapiaz qui naissent sur le calcaire des régions karstiques. Des observations climatiques et chimiques indiquent que ces formes sont dues à des mécanismes de mise en solution, et que cette région nous montre une microtopographie karstique sur quartzite.

\section{REFERENCES}

BöGLI, A. (1960) - Kalklösung und Karrenbildung. Zeitschr. Geomorph., Supp. 2, Karstmorphologie: 4-21.

Klaer, W. (1957) - Verwitterungsformen im Granit auf Korsika. Erdkunde 11: $1-156$.

Krauskopf, K. B. (1956) - Dissolution and Precipitation of Silica at Low Temperatures. Geochim. Cosmochim. Acta 10: 1-26.

Lopez, V. M., Mencher, R., and Brineman, J. H. (1942) - Geology of Southeastern Venezuela. Geol. Soc. Am. Bull. 53: 849-872.

Morey, G. W., Fournier, R. O., and Rowe, J. J. (1962) - The Solubility of Quartz in Water in the Temperature Interval from $25^{\circ} \mathrm{C}$. to $300^{\circ} \mathrm{C}$. Geochim. Cosmochim. Acta 26: 1029-1043.

Rasmusson, G. (1959) - Karstformen im Granit des Fichtelgebirges. Die Höhle 10:1-4.

Snelling, N. J. (1963) - Age of the Roraima Formation, British Guiana. Nature 198: 1079.

Tate, G. H. H. (1938) - Auyantepui. Geograph. Rev. 28: 452-474.

WoJcık, Z. (1961) - Karst Phenomena and Caves in the Karkonosze Granites. Die Höhle 12: 1-44. 